\title{
Awareness of politicians in implementing political education to realize political voluntarism in buleleng
}

\author{
A. A. Istri Dewi Adhi Utami ${ }^{1}$, I Putu Hendra Mas Martayana ${ }^{2}$ \\ \{adhi.utami@undiksha.ac.id ${ }^{1}$, mas.mertayana@undiksha.ac.id² ${ }^{2}$ \\ Universitas Pendidikan Ganesha, Indonesia ${ }^{1,2}$
}

\begin{abstract}
This study aims to describe the awareness of politicians in carrying out their political education functions in order to realize the political voluntarism in Buleleng regency in welcoming the simultaneous regional leader elections in 2022. This study uses a qualitative descriptive research approach. The research data analysis used by qualitative method. The results of this study indicate that the characteristics of political voluntarism in Buleleng regency are still low level. The factors that can influence the emergence of citizen political volunteerism in Buleleng regency include personal factors of politicians, socioeconomic, cultural and political factors, the influence of globalization and modern democracy, mass media and factors of law enforcement. Politicians are expected to better interpret and understand, then implement their duties and functions in increasing awareness of politicians in carrying out the function of political education in order to realize the political voluntarism of citizens in Buleleng.
\end{abstract}

Keywords: politicians; political education; political voluntarism

\section{Introduction}

The success in holding general elections is one of success barometer of a country that adopts a democratic system [1]. This is determined by the level of citizen's participation. Participation is an active process and initiative in an activity. In Indonesia, citizen's participation in politics is guaranteed by the state. This is stated in Constitution of Indonesia (UUD 1945 pasal 28). In addition, it is also regulated in Undang-Undang Nomor 12 tahun 2005 concerning the guarantee of International Covenant Civil and Political Rights [2].

The phenomenon of low citizen's political participation in general elections is reflected from the implementation in each city or regency, such as in Buleleng Regency. In legislative elections 2004, citizen's political participation rate of Buleleng was 326,498 voters (75\%) of 434,018 final voters list. So there are about $25 \%$ voters who do not use their voting rights. In the election 2009, there were 480,420 voters, but 332.799 voters exercised their voting rights (68.67\%). However, in Presidential Election 2009, there was a decline of $65.26 \%$ and $34.74 \%$ of those who did not use their voting rights. In presidential election 2014, there were 543,542 registered voters, but those who used their voting rights were 337,277 voters $(62.05 \%)$ and those who did not use their voting rights were $37.95 \%$ (data from Regional Genaral Comisional 
Election Buleleng Regency / KPUD Kab. Buleleng, 2014). In regent election of Buleleng regency 2017 has 54.4\% citizens participation rate, while in gavernor election 2018, participation rate of Buleleng is $58.4 \%$ [3]. But there was an increase in voter participation in the election 2019, where out of 595,032 DPT who exercised their voting rights amounted to 439,787 or $73.91 \%$, but this figure is still lower than the overall participation rate in Bali province with a citizen participation rate of $81.84 \%$ and the lowest in between urban districts in Bali, data from KPU Buleleng, 2020 [4]

One of the challenges faced in holding of general and regional elections today is the low level of political participation and political voluntarism of citizens. The large percentage of voters who do not exercise their voting rights in range of $25 \%-37 \%$ indicates that there is a tendency of citizens participation rate in Buleleng Regency. In fact, on the other hands, shows euphoria of election participants. However, this was not followed by high political participation.

The synergy of all policy makers regarding the interests of the General Election is expected to solve this problem. Especially, in order to provide appropriate socialization to the public about the importance of elections for the life of the nation and state. All elements of this nation certainly hope that people's political participation will be high in theregional leader elections (Pilkada) in 2022 , both in quantity and quality in Buleleng district. For this reason, various institutions, both government-owned and non-government institutions, must be able to form smart voters in the concept of active participation and citizen volunteerism in politics (political voluntarism). Through intelligent voters, it is hoped that representatives of the people with high integrity and quality will be elected who can produce policies that are expected by the community. Based on the above, it is this that provides a stimulus to researchers to study and describe how the awareness of politicians to carry out their political education functions in order to realize the political volunteerism of citizens in Buleleng, especially in welcoming the simultaneous regional elections in 2022.

\section{Method}

This research uses a qualitative approach with qualitative descriptive research method design [5]. In this case, the problem is focused on description of politicians' awareness in providing political education to realize the political volunteerism of citizens in Buleleng regency. The subject of this research is phenomenon of low level citizens political participation in Buleleng. In addition, it uses a qualitative data analysis [6].

This research begins with sending a questionnaire and is continued with in-depth interviews with parties involved in the election both organizationally and personally, namely the General Election Commission of Buleleng Regency, KPPS, the general election committee at the village level, to the voters. Voters are divided into two groups, namely those who come to vote and those who do not. The results of this data are then synergized with the results of observations in several locations for the implementation of general elections. Furthermore, comparisons were made with existing documents in the form of data on the number of voters in the Buleleng district, voters who came and not at each polling place. 
Overall data was analyzed interactively until conclusions were drawn about the level of voter participation in the Buleleng district in depth. To deepen the understanding of the results of this study, this analysis process uses political, socio-cultural, and educational theories.

\section{Results and Discussion}

\section{Citizens Political Volunteerism of Buleleng Regency}

Political voluntarism in Buleleng regency can be described from characteristics and types of political activities that are participated during general elections, legislative elections, and presidential elections. There were several types of characteristics and types of political activities carried out by residents of Buleleng regency. (1) Actively registering as a candidate for voters; (2) Promote voter registration to neighbors; (3) Assisting TPDP in recording population of prospective voters; (4) Actively participating in socialization of regent election from and by Regional Genaral Comisional Election (Komisi Pemilihan Umum) or from the media; (5) Actively participating in campaigns of the candidate pairs of regents and deputy regents; (6) Actively participating in village meetings by Komisi Pemilihan Umum (KPU) regarding the implementation of regent elections; (7) Active and volunteering to become a team of one candidate pair; (8) Active discussion about quality of district head elections and quality of candidate pairs; (9) Active as chairman and / or member of PPS; (10) Active as a witness / observer of election implementation; (11) Active in socializing on social media about the election of regents and the choice of candidates; (12) Active as a donor for one of the pairs of candidates; (13) came to the polling station and voted [7].

From these characteristics, it can be said that the citizens political volunteerism of Buleleng Regency is still low. This is evidenced by several reasons. First, citizens are forced to follow other people's interests, especially in practical political activities such as coming to polling stations and voting. Second, citizens only carry out their obligations as citizens. Third, because they get money from election contestants. Fourth, showing vote's right as citizens. Fifth, they want to participate in determining the candidate for Buleleng leader in next five years.

Tabel 1: Category of Citizens Political Participation Rate in Regional Leader Election Buleleng Regency 2017

\begin{tabular}{llrrrr}
\hline & \multicolumn{1}{c}{ Category } & Frequency & Percent & Valid & Cumulative \\
Percent & Percent \\
\hline Valid & $1-3$ (Vary Bad) & 337 & 86.6 & 86.6 & 86.6 \\
& $4-5$ (Bad) & 44 & 11.3 & 11.3 & 97.9 \\
& $6-8$ (Normal) & 8 & 2.1 & 2.1 & 100.0 \\
$9-10$ (Good) & 0 & 0.0 & 0.0 & 100.0 \\
$11-13$ (Vary Good) & 0 & 0.0 & 0.0 & 100.0 \\
\cline { 2 - 6 } & Total & 389 & 100.0 & 100.0 & \\
\hline
\end{tabular}

This data shows that the level of citizen political participation in the Buleleng Pilbup in 2017 is still low [7]. 
Tabel 2. The Level of Citizen Political Participation in Regional Leader Election Buleleng Regency 2017

\begin{tabular}{llrrrr}
\hline Data & Category & Frequency & Percent & Valid Percent & Cumulative Percent \\
\hline Valid & 1 = abstain & 139 & 35.7 & 35.7 & 35.7 \\
& $2=$ voter & 250 & 64.3 & 64.3 & 100.0 \\
\cline { 2 - 6 } & Total & 389 & 100.0 & 100.0 & \\
\hline
\end{tabular}

Based on the analysis conducted, the culture of participation and political volunteerism of citizens in Buleleng Regency is still colored by tendency of Patron-Client culture, moving on subject-participant culture and parocial-participant culture [8][9]. This is evidenced by the existing political culture in Buleleng Regency with the following characteristics; First, PatronClient, explains that culture is seen from relationship patterns and contexts that are individual. This interaction is individual. There is a relationship between patron and client. Patron has resources in form of power, position, protection, attention, material resources (property, land, and money), while client has resources in form of manpower, support and loyalty [10].

\section{The political culture in Buleleng}

The political culture in Buleleng Regency affects legal culture and the level of legal awareness of citizens. In accordance with the theory put forward by Lawrence M. Friedmann [11], legal culture includes the valuesthat underlie applicable law, valueswhich are abstract conceptions of what is good and what is considered bad. Judging from its definition, legal culture defined as people's attitudes towards law and legal system such as beliefs, values, ideas, and expectations [11]. The culture of political participation and political volunteerism that has developed in Buleleng regency as mentioned above is still concerned with conventional practices with primordial principles, status quo, patron-client, paternalism, and kinship so that it has an influence on the legal culture that surrounds it, where culture the law that is influenced will be Top-Down, that is, from the leader to his subordinates, or in other words, from the politicians, the political elite to the constituents[12]. So why in this pattern is known as the RuleModel pattern or modeling or influencing subordinates or convincing supporters (constituents) [13].

The legal awareness of the politicians themselves as the influence of the legal culture in contact with their political culture can be analyzed, understood and known from the indicators that have been described previously, namely indicators of legal awareness of politicians in Buleleng that can be seen from the levels: Knowledge of the Law, Understanding of the Law, Attitude, and Legal Behavior. First, legal knowledge, namely legal knowledge of politicians in Buleleng Regency regarding certain behaviors regulated by Law of the "Undang-Undang Republik Indonesia Nomor 2 Tahun 2008 about Partai Politik", especially in the regulations governing their political education function. Second, understanding the law; Legal understanding is a number of information held by politicians in Buleleng district regarding the contents of Law of the Republic of Indonesia Number 2 of 2008 concerning Political Parties. Or the meaning of the content and objectives of Law of the "Undang-Undang Republik Indonesia Nomor 2 Tahun 2008 about Partai Politik", as well as their benefits for parties whose 
lives are regulated by Law of the Undang-Undang Republik Indonesia Nomor 2 Tahun 2008 about Partai Politik. Third, Legal Attitude, this is a tendency to accept the Law of theUndangUndang Republik Indonesia Nomor 2 Tahun 2008 about Partai Politik. Fourth, the pattern of legal behavior. The pattern of legal behavior is the actions of politicians who are carried out in accordance with Law of the Undang-Undang Republik Indonesia Nomor 2 Tahun 2008 about Partai Politikconcerning Political Parties which is an implementation of the interpretation and actualization of politicians towards the law [14]; [15].

The legal awareness of politicians which is reflected in the knowledge, understanding, attitudes, and behavior patterns that are displayed will also affect the legal awareness of their constituents[16]. Where, as explained earlier, the existence of exemplary and Rule-Model will be able to have a positive influence on the legal awareness of society through its constituents. That effectiveness of legislation can be said to occur in society[17]. So that it can be explained about the awareness of politicians in carrying out the function of political education in order to realize the political volunteerism of citizens in Buleleng district in welcoming the simultaneous regional elections in 2022, namely as follows; Political Education for Internal Political Parties, Political education aims to provide knowledge, understanding, inculcation of attitudes and manifesting behavior patterns of politicians themselves[18]. This means that political education is carried out for politicians in political parties as outlined in the vision, mission and work program of the political party concerned, namely in the following forms; The first is Consolidation, the politicians in Buleleng regency, through the life of their political party organizations, there will always be a process of consolidation and socialization. Consolidation concerns the interests of the party (its political party platform) which is associated with the socialization function of political parties to strengthen unity and integrity and identity within the party concerned[19]. Consolidation is manifested in the form of socialization activities on ideology and political party platforms, which include: socialization of political parties' statutes, visions, missions, and work programs which politicians in political parties must know, understand, address and implement. Consolidation aims to create the highest possible sense of solidarity and dedication, as well as loyalty from politicians, party elites and party cadres to their parties[20].

\section{Consolidation of Political Parties}

Looking at the programs of political parties that are the object of this research, it can be identified into several forms of consolidation carried out according to translation or understanding of political parties concerned in Buleleng Regency, they are; structural party consolidation, party structure consolidation is carried out in form of; Party Branch Conferences, this will be held in 9 (nine) regencies / cities in province Bali. Party Branch Conference for Children, this is carried out in every sub-district in Bali. Party Subdistrict Deliberations, carried out by the branches that have formed PAC Party management Bali, and Branch Children Meeting. Non Structural Consolidation, consolidation is very important in winning elections[21].

Consolidation of non-party structures is carried out by forming and establishing a Party Regional Advisory Council, forming and establishing departments according to division of tasks 
in accordance with fields determined by party. Internal party consolidation with main objectives as follows; strengthening party loyalty to Pancasila and UUD 1945 and NKRI, strengthening appreciation and practice of party cadres and members on basic of struggle, vision, mission and party discipline, conducting introspection of party performance based on experience and being responsible for development and progress of party, forming and solidifying image of party[18].

Then, there is also the type of consolidation in an effort to succeed in party consolidation and development. First, ideal consolidation. This consolidation aims to strengthen party loyalty to Pancasila and UUD 1945 and maintain the upholding of Unitary Republic of Indonesia, improve practice of party ideology, increase moral awareness, ethics and exemplary. Secondly, consolidation of insights, this consolidation aims to solidify the insight of nationalism and insight of archipelago, develop global insights in the perspective of national interests[22]. Third is organizational consolidation. This consolidation tends to be like a structural consolidation, which concerns membership sector; institutional regeneration; extracting and utilizing funds; relations with social and professional organizations; in the field of cooperation, synergy with other political parties; and information and mass media, research and development as well as law and human rights development [23].

\section{Political Voluntarism in Covid-19 Pandemic Era}

In this year, many party officials who will run for Regional Election 2020 have come to public to campaign for the dangers of COVID-19 and the ways of transmission. This activity was generally accompanied by distribution of aid for nine basic necessities (sembako), food, disinfectants, and personal protective equipment (PPE). Not only that, several members of parliament at local and national levels have also stated that they will donate part of their salary to ward off growing spread of COVID-19 outbreak.Several political parties conveyed instructions and established special programs against COVID-19. Partai Demokrat (PD), Partai Demokrasi Indonesia Perjuangan (PDIP) and Partai Kebangkitan Bangsa (PKB) have conveyed instructions for party cadres to take part in breaking the chain of COVID-19. Meanwhile, several other parties including Partai Golongan Karya and Partai Nasional Demokrat have special programs which they call: "Gerakan Golkar Peduli Lawan COVID-19" and "Gerakan Nasdem Peduli” [24].

The steps taken by these political parties must be appreciated. However, there are notes that also need to be observed. Parties should be able to take advantage of broad network of political party cadres and use the ability of parties to tie up their cadres. The strength of this cadre is what distinguishes party programs from aid programs or donations made by individuals or civil society groups[21]. Party administrators and party wing organizations can be mobilized to map the problems and needs of constituents after the outbreak of this corona virus. There are several factors that can influence the emergence of citizen political volunteerism in Buleleng Regency, they are personal factors of politicians, socio-economic, cultural and socio-political factors, socialization of legislation products, influence of globalization and modern democracy, communication media and the masses and factors of the casualties. Personal factors are defined as anything that can affect legal awareness of politicians in carrying out their political education functions that originate from within themselves [25]. 


\section{Conclusions}

Politicians in Buleleng Regency are expected to better interpret and understand, then implement their duties and functions in increasing awareness of carrying out the function of political education in order to realize citizens political volunteerism in Buleleng Regency. Undang-Undang Nomor 2 tahun 22008 about Political Parties, it is hoped that political life in Buleleng Regency will lead to a political culture, community participation and conventional practices with primordial principles, status quo, patron-client, paternalism, and kinship to realize implementation of democracy modern based on the valuesof Pancasila and UUD 1945 in Indonesia. It is hoped that political parties, through their politicians, will further improve their political education functions with aim of increasing the participation of the Buleleng Regency people in efforts to increase their rights and obligations as citizens to determine direction of public policy, so that national goals are achieved and not only limited to political participation in voting in general election.

\section{References}

[1] S. Marzuki, "Peran Komisi Pemilihan Umum Dan Pengawas Pemilu Untuk Pemilu Yang Demokratis," J. Huk. Ius Quia Iustum, vol. 15, no. 3, hal. 393-412, 2008, doi: 10.20885/iustum.vol15.iss3.art8.

[2] Pemerintah Republik Indonesia, "Undang-Undang Nomor 12 Tahun 2005 tentang International Covenant on Civil and Political Rights," no. 1, 2005.

[3] B. Nusa, "Golput di Buleleng Tembus 45,57 Persen," 23 Februari 2017, 2017. .

[4] B. KPU, "Partisipasi dalam pemilu sangatlah penting, karena berkaitan dengan legitimasi," 04 Agustus 2020, 2020. .

[5] J. W. Creswell, Educational Research. Planing, Conducting, and Evaluating Qualitative \& Quantitative Approaches. London: Sage Publications, 2008.

[6] M. B. Miles dan M. A. Huberman, Qualitative Data Analysis. New Delhi, 1994.

[7] Sukadi, I. N. Suastika, dan I. W. Budiarta, "Partisipasi Memilih Warga Pada Pilbup Buleleng Tahun 2017," Buleleng, 2017.

[8] A. Gafar, Politik Indonesia” Transisi Menuju Demokrasi. Yogyakarta, 2004.

[9] A. Purwanti, "Partisipasi perempuan pada lembaga legislatif tahun 2014-2019 di provinsi jawa timur," Masal. Huk., vol. 44, no. 2, hal. 190, Apr 2015, doi: 10.14710/mmh.44.2.2015.190-199.

[10] PLaCID's, Program Sekolah Demokrasi kerjasama dengan Public Policy analysis and Communitiy Development Studies (PLaCID's) AVERSOS dan Komunikasi Indonesia untuk Demokrasi (KID) buku seri demokrasi ke-6. Budaya politik indonesia. Malang, 2007.

[11] M. Mahfud, Politik Hukum di Indonesia. Jakarta: PT Raja Grafindo Persada, 2017.

[12] P. S. Nur Wardhani, "Partisipasi Politik Pemilih Pemula dalam Pemilihan Umum," JUPIIS J. Pendidik. ILMU-ILMU Sos., vol. 10, no. 1, hal. 57, Jun 2018, doi: 10.24114/jupiis.v10i1.8407.

[13] S. Pemerintahaan-Indonesia.blogspot.co.id, "Pemilu di Indonesia | Sistem Pemilihan Umum,” $J$. Ilmu Sos. dan Ilmu Polit., 2013. 
[14] M. D. A. Muallifin, "Problematika Dan Pemberantasan Korupsi Di Indonesia," Ahkam J. Huk. Islam, vol. 3. No. 2, hal. 311-325, 2015, doi: 10.21274/ahkam.2015.3.2.311-325.

[15] K. Mastini dan M. A. Azhar, "Faktor Tingginya Partisipasi Politik Masyarakat Desa Sidetapa Pada Pemilu Legislatif Tahun 2014," hal. 1-9, 2014.

[16] M. B. D. Cahyo, "Tingkat Partisipasi Masyarakat dalam Menggunakan Hak Suara pada Pemilu Legislatif 2014," Pandecta Res. Law J., vol. 10, no. 1, Jun 2015, doi: 10.15294/pandecta.v10i1.4197.

[17] T. TRIONO, "Menakar efektivitas pemilu serentak 2019," J. Wacana Polit., vol. 2, no. 2, Okt 2017, doi: 10.24198/jwp.v2i2.14205.

[18] P. P. A. Saifulloh, "Kewajiban Partai Politik Berideologi Pancasila Ditinjau dari Prinsip-Prinsip Negara Hukum Indonesia,” andecta Res. Law J., vol. 11, no. 2, hal. 174-188, 2017, doi: https://doi.org/10.15294/pandecta.v11i2.9276.

[19] M. Muslihudin et al., "Sistem pendukung keputusan penentuan calon pemohon pembiayaan nasabah menggunakan metode simple additive weighting (saw) (Studi Kasus: BTPN Syariah Kantor Fungsional Operasional Ciawi Kabupaten Tasikmalaya)," J. TAM (Technology Accept. Model., 2019, doi: 10.36723/juri.v8i2.129.

[20] T. Sulityaningtyas, "Representasi calon presiden dan calon wakil presiden dalam iklan politik luar ruang partai demokrat," Ranah J. Kaji. Bhs., vol. 3, no. 1, hal. 60, Jun 2014, doi: 10.26499/rnh.v3i1.47.

[21] I. Sina Chandranegara, S. Bakhri, dan N. Sahputra Umara, "Optimalisasi pembatasan dana kampanye pemilihan umum kepala daerah sebagai pencegahan investasi politik yang koruptif," Mimb. Huk. - Fak. Huk. Univ. Gadjah Mada, vol. 32, no. 1, hal. 30, Feb 2020, doi: 10.22146/jmh.47512.

[22] E. Nurussa'adah dan S. Sumartias, "Komunikasi politik partai keadilan sejahtera (pks) dalam keterbukaan ideologi,” J. Kaji. Komun., vol. 5, no. 1, hal. 43, Jun 2017, doi: 10.24198/jkk.v5i1.8522.

[23] N. W. Widhiasthini, "Qua Vadis Pemberlakuan PKPU Nomor 7 Tahun 2015 Dan PKPU Nomor 5 Tahun 2015 Terhadap Partisipasi Pemilih Masyarakat Dalam Pilkada 2015 Di Provinsi Bali," vol. 6, no. 1, hal. 49-60, 2015.

[24] Z. Amirudin, "Model communication enggagement dalam komunikasi politik calon legislatif dalam pemilu umum 2014," vol. 45, no. 2, hal. 115, Feb 2016, doi: 10.21831/informasi.v45i2.7987.

[25] I. G. Made, A. Suta, dan K. S. Dewi, "Dinamika politik identitas masyarakat muslim bali pada pilgub bali tahun 2018 . Pendidikan Sosiologi, Universitas Pendidikan Ganesha. vol. 6, no. 1, hal. $40-57,2018$. 